\title{
HER2's new mutations
}

\section{By Tim Fulmer, Senior Writer}

Washington University in St. Louis School of Medicine researchers have used next-generation sequencing to identify mutations in HER2 that are missed by standard screening tests that identify only amplifications. ${ }^{1}$ Based on the findings, the researchers are now recruiting patients with breast cancer expressing the mutations for a Phase II trial of Puma Biotechnology Inc.'s HER2-targeting compound, neratinib.

Amplification of the gene encoding HER2 (EGFR2; ErbB2; neu) is a driver of aggressive forms of breast cancer and occurs about $23 \%$ of the time. ${ }^{2}$ Based on 2012 epidemiological data from the American

\section{"Based on the findings,} we are now launching a Phase II trial to test neratinib in breast cancer patients who are negative for HER2 amplification but positive for HER2 somatic mutations."

-Ron Bose,

Washington University in St. Louis School of Medicine

and the small molecule Tykerb lapatin plc. Neratinib, also a small molecule, is in Phase I/II testing to treat metastatic breast cancer. That trial is distinct from the new trial.

Using next-generation genome sequencing methods, researchers have recently begun identifying HER2 somatic mutations in patients with breast cancer who test negative for HER2 amplification. ${ }^{3-5}$ Those findings have raised the question of whether HER2 somatic mutations are also drivers of the disease and, if so, whether they would respond to any of the therapies on the market or in development.

HER2 somatic mutations are not detectable by standard methods used to identify HER2 amplification, which rely on fluorescence in situ hybridization and immunohistochemistry.

The Washington University team, led by professors of medicine Ron Bose and Matthew Ellis, first analyzed data from 8 breast cancer genome sequencing projects in more than 1,500 patients. They identified 25 patients who had HER2 somatic mutations but lacked HER2 amplification.
That result gave a mutational frequency of about $1.6 \%$, which translates to about 4,000 patients per year in the U.S. who might carry at least one HER2 somatic mutation. A total of 16 different HER2 somatic mutations were identified in the study, some of which were shared by multiple patients.

In cell culture, 7 of the 16 HER2 somatic mutations tested led to increased epidermal growth factor receptor (EGFR) signaling compared with wild-type HER2, confirming that they were activating mutations. In mouse xenografts, transplanted breast cancer cells bearing some of those activating mutations formed tumors more rapidly than transplanted cells expressing wild-type HER2.

To see if the mutations responded to current therapies, the researchers showed that neratinib inhibited growth of a panel of cell lines individually expressing the 7 activating mutations with $\mathrm{IC}_{50}$ values of $<2 \mathrm{nM}$. However, in the same cell lines, lapatinib was less potent, with some lines even showing resistance to the compound.

The findings were published in Cancer Discovery.

"Based on the findings, we are now launching a Phase II trial to test neratinib in breast cancer patients who are negative for HER2 amplification but positive for HER2 somatic mutations," corresponding author Bose told SciBX.

The single-arm, open-label trial is expected to last about 2 years, with the goal of treating about 30 patients, said Bose. Besides Washington University, three other institutions will participate in the trial: the Dana-Farber Cancer Institute, the Memorial SloanKettering Cancer Center and The University of North Carolina at Chapel Hill.

"We will use the same neratinib doses as are used in the other ongoing breast cancer trials and, during the course of the trial, we will use CAT scan to measure tumor size in response to treatment," said Bose.

Puma Biotechnology is sponsoring the trial, said Alan Auerbach, president, CEO and founder. "We anticipate expanding the trial to include additional centers beyond the original four," he said. "In addition, we are interested in partnering to develop a companion diagnostic that identifies HER2 somatic mutations and guides the use of neratinib in cancer patients expressing those mutations."

Auerbach said HER2 somatic mutations also occur in lung, colon and gastric cancers. "We would thus eventually be interested in running trials of neratinib in those indications as well," he said.

Puma exclusively licensed neratinib from Pfizer Inc. in 2011. According to Auerbach, the compound is in six ongoing Phase I and Phase II trials, as both a single agent and in various combinations, to treat breast and lung cancers.

Unlike the HER2-targeting mAbs, which bind the extracellular portion of HER2, neratinib targets the intracellular tyrosine kinase activity of the receptor, said Auerbach. "We believe that difference gives neratinib a potential advantage in the treatment refractory setting, where the extracellular portion of HER2 is often truncated, making it more difficult to target the receptor with an antibody alone," he added.

Fulmer, T. SciBX 6(2); doi:10.1038/scibx.2013.26

Published online Jan. 17, 2013 


\section{ANALYSIS}

\section{REFERENCES}

1. Bose, R. et al. Cancer Discov.; published online Dec. 7, 2012; doi:10.1158/2159-8290.CD-12-0349

Contact: Ron Bose, Washington University in St. Louis School of Medicine, St. Louis, Mo.

e-mail: rbose@dom.wustl.edu

Contact: Matthew J. Ellis, same affiliation as above e-mail: mellis@dom.wustl.edu

2. Owens, M.A. et al. Clin. Breast Cancer 5, 63-69 (2004)

2. Ellis, M.J. et al. Nature 486, 353-360 (2012)

3. Lee, J.W. et al. Clin. Cancer Res. 12, 57-61 (2006)

4. Shah, S.P. et al. Nature 461, 809-813 (2009)

5. Shah, S.P. et al. Nature 486, 395-399 (2012)
COMPANIES AND INSTITUTIONS MENTIONED

American Cancer Society, Atlanta, Ga.

Dana-Farber Cancer Institute, Boston, Mass.

Genentech Inc., South San Francisco, Calif.

GlaxoSmithKline plc (LSE:GSK; NYSE:GSK), London, U.K.

Memorial Sloan-Kettering Cancer Center, New York, N.Y.

Pfizer Inc. (NYSE:PFE), New York, N.Y.

Puma Biotechnology Inc. (NYSE:PBYI), Los Angeles, Calif.

Roche (SIX:ROG; OTCQX:RHHBY), Basel, Switzerland

The University of North Carolina at Chapel Hill, Chapel Hill, N.C.

Washington University in St. Louis School of Medicine,

St. Louis, Mo. 